\title{
PENGEMBANGAN SISTEM BIOFILTRASI UNTUK MEMPERTAHANKAN MUTU AIR PADA PENAMPUNGAN LOBSTER HIJAU PASIR (Panulirus humarus) HIDUP DENGAN RAK BERTINGKAT
}

\author{
Th. Dwi Suryaningrum*), Singgih Wibowo*), Sri Amini*), dan Bagus Sediadi Bandol Utomo*)
}

\begin{abstract}
ABSTRAK
\end{abstract}
Penelitian rancang bangun penampungan lobster dengan menggunakan bak serat kaca bertingkat yang dilengkapi dengan sistem biofiltrasi untuk mempertahankan mutu air pada penampungan lobster hijau pasir (Panulirus humarus) telah dilakukan. Sistem biofiltrasi disusun dengan menggunakan dua macam bahan, yaitu pasir dalam bak tersendiri dan koral dalam bak bersekat, kemudian diinokulasi dengan lumpur tambak dan dibiarkan selama dua minggu. Air hasil filtrasi digunakan untuk penampungan dan pembugaran lobster. Pengamatan dilakukan terhadap besarnya debit air yang keluar dari sistem biofiltrasi yang dibentuk, efektivitas biofiltrasi terhadap mutu air, serta efektivitas sistem penampungan terhadap lobster hijau pasir selama 1 bulan. Selama penampungan dilakukan pengamatan kondisi lobster dan mutu air. Hasil penelitian menunjukkan bahwa filter pasir yang ditempatkan pada bak tersendiri menghasilkan aliran air dengan debit $20 \mathrm{~L} /$ menit dan filter koral dalam bak besekat debitnya sebesar $10 \mathrm{~L} /$ menit. Sistem biofiltrasi yang dibentuk setelah 2 minggu mempunyai kandungan bakteri di dalam koral sebesar $36,24 \times 10^{12} \mathrm{sel} / \mathrm{g}$ dan mampu memperbaiki keasaman air dari pH 6,84 (agak asam) ke pH 7,82 (pH air laut normal), serta mampu mereduksi senyawa metabolik amonia dari $0,164 \mathrm{mg} / \mathrm{L}$ menjadi $0,085 \mathrm{mg} / \mathrm{L}$; nitrit $0,08 \mathrm{mg} / \mathrm{L}$ menjadi $0,069 \mathrm{mg} / \mathrm{L}$ dan protein $0,51 \%$ menjadi $0,42 \%$ setelah air dialirkan selama 2 jam dalam sistem biofltrasi. Penambahan air akan menyebabkan kestabilan sistem biofiltrasi terganggu. Penampungan yang dilengkapi dengan sistem biofiltrasi ini dapat menampung lobster selama 30 hari lebih. Selama penampungan, sistem biofiltrasi yang dibentuk mampu mereduksi senyawa metabolik beracun hingga aman untuk penampungan lobster dalam jangka waktu lama. Penampungan tidak berpengaruh terhadap bobot individu lobster. Selama penampungan, tingkat kematian lobster terjadi pada minggu pertama dan kedua sedangkan minggu ketiga dan keempat tidak terjadi kematian. Kondisi dan aktivitas lobster sangat bugar setelah 2 minggu penampungan.

ABSTRACT: Development of biofiltration system for maintaining water quality during life holding of spiny lobster (Panulirus humarus) in multilevel tank. By: Th. Dwi Suryaningrum, Singgih Wibowo, Sri Amini, and Bagus Sediadi Bandol Utomo

A study on biofiltration system for maintaining water quality during life holding of life spiny lobster (Panulirus humarus) in multilevel fiber glass tank has been conducted. The biofiltration system was made of sand and rock filters which had been inoculated with bacteria from mud of shrimp pond and left for two weeks. The filtered water was then used for holding life lobster. Observation during one moth holding experiment of life spiny lobster showed that the water debits of the sand and rock filter, were $20 \mathrm{~L} / \mathrm{min}$ and $10 \mathrm{~L} /$ min respectively. After two weeks, rocks in biofiltration system contained $36.24 \times 10^{12}$ bacteria/g. The system was able to increase the $\mathrm{pH}$ water from 6.84 to 7.82 , as well as to reduce amonia content form $0.164 \mathrm{mg} / \mathrm{L}$ to $0.085 \mathrm{mg} / \mathrm{h}$, nitrit from $0.08 \mathrm{mg} / \mathrm{L}$ to $0.069 \mathrm{mg} / \mathrm{L}$ and protein from $0.51 \%$ to $0.42 \%$ after 2 hour resirculation of water in biofiltration system. The addition of water to the filtration system affected the system stability. This system could hold lobster for more than 30 days. During holding experiment the biofiltration system could reduce toxic metabolites to a save condition for a long period. This system did not affect the weight of individual lobster, but affected the survival rate of lobster, particulary during the first and second weeks of experiment.

KEYWORDS: Iobster, biofiltration, life holding, multilevel tank

\section{PENDAHULUAN}

Salah satu syarat yang sangat menentukan keberhasilan transportasi lobster hidup adalah kondisi kesehatan dan kebugaran lobster sebelum ditransportasi. Untuk menyediakan lobster hidup dalam kondisi sehat dan bugar sebelum transportasi diperlukan tempat penampungan yang memenuhi persyaratan tertentu untuk mempertahankan mutu airnya. Mutu air selama penampungan merupakan

Peneliti pada Pusat Riset Pengolahan Produk dan Sosial Ekonomi Kelautan dan Perikanan 
faktor kritis, karena selama penampungan terjadi akumulasi bahan organik seperti kotoran lobster dan sisa pakan. Melalui proses dekomposisi, bahan organik tersebut akan diuraikan menjadi senyawa yang bersifat racun seperti amonia dan nitrit. Senyawasenyawa tersebut sulit diatasi secara fisik dan kimiawi, sehingga dapat menyebabkan terjadinya penurunan mutu air yang berakibat terhadap menurunnya kebugaran atau kematian lobster. Di samping itu proses dekomposisi sendiri banyak mengkonsumsi oksigen, sehingga menyebabkan menurunnya kelarutan oksigen di dalam air (Suastika et al., 1996)

Dengan memanfaatkan jasad biologi seperti bakteri yang bersifat remediasi, senyawa metabolik yang bersifat racun tersebut dapat diubah menjadi senyawa yang tidak beracun dalam air. Bakteri yang dimanfaatkan dalam mengolah air tersebut adalah bakteri nitrifikasi yang bersifat aerobik seperti Nitrosomonas, yang mampu mengubah amonia menjadi nitrit dan selanjutnya oleh bakteri Nitrobacter sp. nitrit diubah menjadi nitrat. Dalam keadaan anaerob nitrat direduksi oleh bakteri pemecah nitrat menjadi nitrogen (Remmerswall, 1993; Suastika et al., 1996). Dengan demikian senyawa metabolit yang dihasilkan oleh lobster diubah menjadi senyawa yang tidak berbahaya dan aman untuk penampungan. Jika senyawa metabolik lobster ini dapat diatasi, maka kondisi lobster akan lebih bugar selama penampungan beberapa hari sehingga menghasilkan sintasan hidup yang tinggi selama transportasi (Basyarie, 1990; Berka, 1986; Praseno, 1990). Penampungan juga diperlukan karena dalam praktek biasanya lobster yang dipasarkan hidup tidak dapat langsung dikirim ke konsumen atau eksportir karena beberapa pertimbangan, misalnya tempat penangkapan jauh dan terpencar serta adanya pengaturan jadwal pengiriman untuk ekspor.

Praktek penanganan di tempat penampungan lobster selama ini kurang memadai. Tempat penampungan lobster pada umumnya jauh dari laut, sehingga sistem penampungan lobster menggunakan sistem tertutup. Jumlah lobster yang ditampung tidak diperhitungkan dengan jumlah oksigen terlarut dan air yang digunakan. Di samping itu penampungan tidak dilengkapi dengan unit pengolah air atau filtrasi, sehingga banyak lobster yang mati atau lemah karena menurunnya mutu air selama penampungan. Praktek penanganan di tempat penampungan tersebut seringkali menghasilkan tingkat mortalitas yang tinggi sampai 50\% tergantung kondisi dan lama penampungan (Wibowo, 1993).

Oleh karena itu dalam penelitian ini dirancang suatu model sistem penampungan untuk memperbaiki sistem penampungan yang sudah ada. Penampungan ini dirancang dengan menggunakan bak serat kaca bertingkat dan dilengkapi dengan unit biofiltrasi yang memanfaatkan jasad bakteri sebagai filter biologis. Sirkulasi air menggunakan sistem tertutup sehingga lebih efisien, terutama bagi penampung yang jauh dari laut dan yang lahannya sempit. Penelitian ini mencakup konstruksi dan pembentukan sistem biofiltrasi, model penampungan rak bertingkat, serta pengaruhnya terhadap kondisi lobster yang ditampung. Diharapkan dari hasil penelitian ini dapat diperoleh model biofiltrasi dan sistem penampungan lobster serta kondisi lobster selama penampungan.

\section{BAHAN DAN METODE}

\section{Bahan}

Bahan yang digunakan dalam penelitian ini adalah lobster hijau pasir (Panulirus humarus) yang berukuran 3 ekor $/ \mathrm{kg}$ dalam keadaan hidup, sehat dan normal. Lobster diperoleh dari pedagang pengumpul di Pangandaran dan Ciamis, Jawa Barat yang berasal dari hasil tangkapan nelayan dengan jaring dan bubu. Batu koral dan pasir untuk pembentukan sistem biofiltrasi diperoleh dari Pantai Pangandaran. Lumpur tambak sebagai inokulan awal pembentukan sistem biofiltrasi diperoleh dari tambak udang di Tanjung Pasir, Tangerang. Air laut diperoleh dari Gelanggang Samodera Ancol, Jakarta.

\section{Bak biofiltrasi}

Bak biofiltrasi yang digunakan dalam penelitian ini terbuat dari kayu lapis $18 \mathrm{~mm}$, dengan ukuran panjang $240 \mathrm{~cm}$, lebar $60 \mathrm{~cm}$, dan tinggi $40 \mathrm{~cm}$. Bak biofiltrasi kemudian disekat memanjang di tengah-tengahnya sehingga terdiri atas 2 kolom dan masing-masing kolom disekat lagi menjadi 8 sekat. Posisi sekat diatur sedemikian rupa sehingga air mengalir secara bergantian dari atas dan bawah. Untuk air yang mengalir dari bawah, posisi sekat dipasang agak naik, sehingga ada rongga $\pm 10 \mathrm{~cm}$, sedangkan untuk air yang mengalir dari atas, sekat agak pendek sehingga posisinya lebih rendah $10 \mathrm{~cm}$. Bak kemudian dilapis dengan menggunakan serat kaca dan resin (Gambar 1).

\section{Bak penampung lobster}

Bak penampung lobster yang digunakan terbuat dari bahan serat kaca yang berukuran $110 \times 110 \times 25$ $\mathrm{cm}^{3}$, yang dilengkapi dengan sirkulator dan aerator. Bak penampung lobster disusun dalam rak bertingkat tiga yang terbuat dari besi siku, yang juga dilapisi dengan resin untuk menghindari terjadinya proses pengkaratan. Masing-masing tingkat terdiri atas 2 bak yang digunakan sebagai ulangan (Gambar 2). 


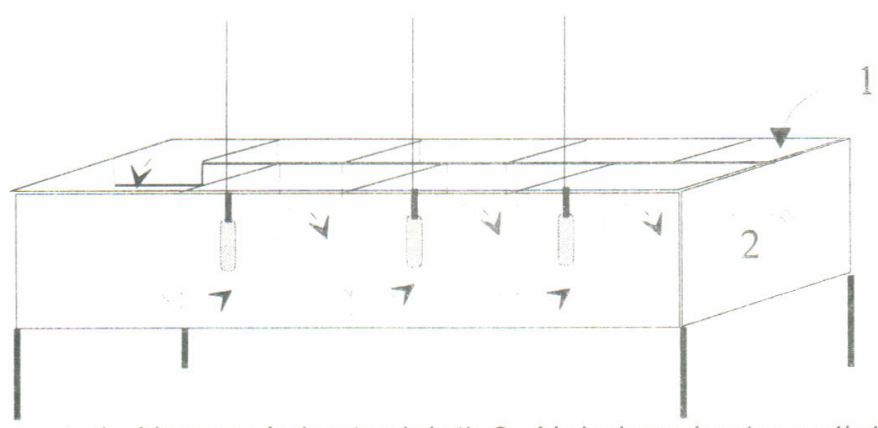

1. Air masuk (water inlet); 2. Air keluar (water outlet),

3. Pipa aerasi (aerasi pipe)

Gambar 1. Bagan penampang bak biofiltrasi

Figure 1. Skema of biofiltration tank

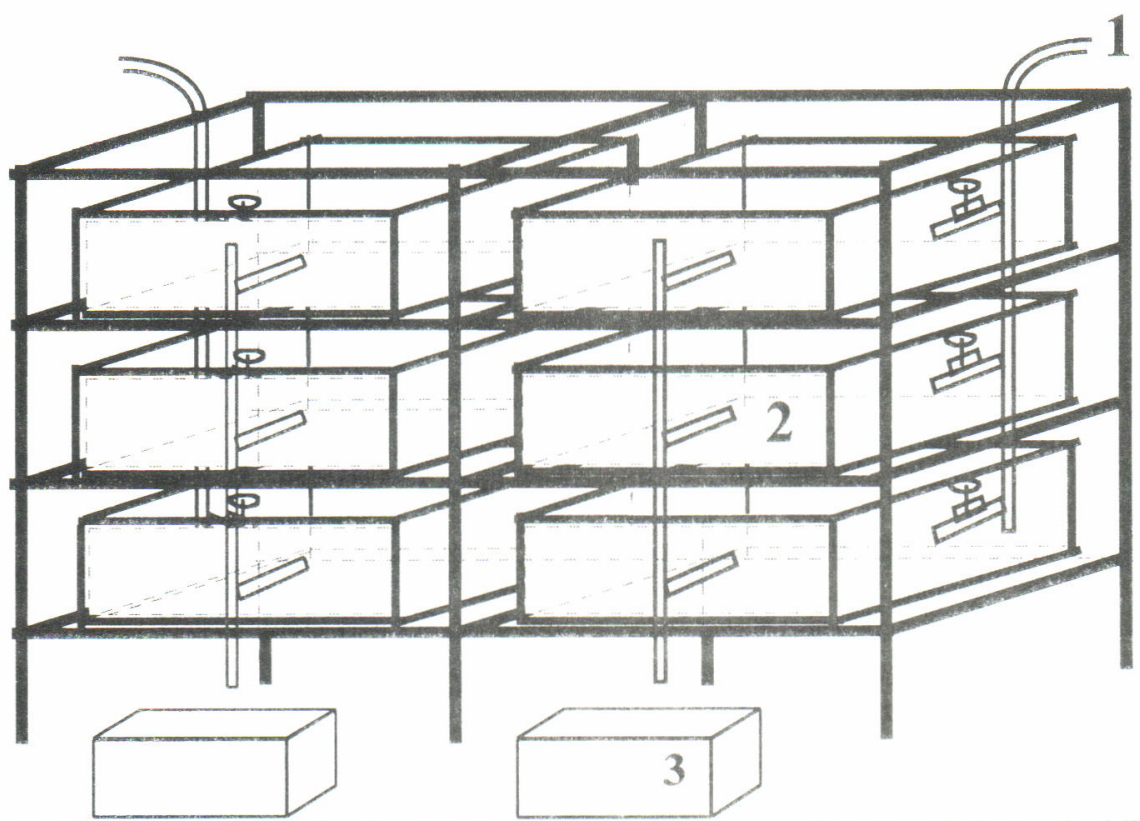

1. Aliran air masuk (water inlet), 2. Bak penampung lobster (lobster holding tank),

3. Bak penampung air buangan (waste water holding tank)

Gambar 2. Bak penampung lobster bertingkat

Figure 2. Multilevel tank for holding lobster

\section{Metode}

\section{Pembentukan sistem biofiltrasi}

Sistem biofiltrasi dibentuk dalam bak filtrasi, menggunakan bahan filter berupa pasir, koral, dan arang yang disusun sedemikian rupa sampai diperoleh aliran air yang cukup. Bahan filter tersebut dimasukkan ke dalam masing-masing kolom bak biofiltrasi dengan susunan sekat kedua dan kelima diisi dengan pasir, sekat ketiga dan keenam diisi dengan arang dan sekat keempat dan ketujuh diisi dengan koral, sedangkan sekat pertama dan kedelapan dibiarkan kosong. Namun dengan susunan yang demikian terjadi stagnasi aliran air pada bak yang diisi filter pasir. Akhirnya ditetapkan bahwa pasir dipisahkan dari koral dan arang tidak digunakan lagi. Filter pasir ditempatkan pada bak serat kaca berukuran $55 \times 55 \times 70 \mathrm{~cm}^{3}$ (kapasitas $200 \mathrm{~L}$ ) dengan ketebalan pasir $15-20 \mathrm{~cm}$ terpisah dari bak biofiltrasi yang diisi koral. Untuk menghindari penyumbatan pasir pada pipa saluran air keluar, pada dasar bak pasir diberi ijuk dengan ketebalan $10-15 \mathrm{~cm}$. Koral ditempatkan pada bak biofiltrasi pada sekat no. 2 sampai dengan no. 7 (bagian tengah), sedangkan 2 bak bagian pinggir dibiarkan kosong. Ketinggian koral dalam tiap-tiap sekat $\pm 30 \mathrm{~cm}$, dan diaerasi secara berselang-seling sehingga memungkinkan bakteri 
yang bersifat aerob dan anaerob tumbuh. Sistem biofiltrasi yang dibentuk ini kemudian diuji kecepatan aliran airnya

Filter kemudian diinokulasi bakteri dengan menggunakan lumpur tambak. Cara mengkulturnya yaitu dengan melarutkan $1 \mathrm{~kg}$ lumpur tambak dalam $1 \mathrm{~L}$ air laut kemudian dimasukkan ke dalam sistem biofiltrasi (bak pasir dan bak bersekat) yang telah diisi dengan 600 liter air laut. Inokulasi ini dimaksudkan untuk menumbuhkan bakteri remediasi pemecah amonia dan nitrit yang secara alami terdapat di lumpur tambak. Kulturisasi bakteri dilakukan dengan cara mengalirkan air laut ke dalam sistem biofiltrasi serta diaerasi selama 15 hari untuk memberi kesempatan bakteri tumbuh. Aliran air laut digerakkan dengan menggunakan pompa sirkulator rhena 300 , sedangkan aerasi digerakkan dengan aerator Hi Blow. Setiap minggu dilakukan pengamatan terhadap jumlah bakteri (TPC) baik pada koral maupun air dengan metode tuang.

Efektivitas sistem biofiltrasi diuji dengan mengalirkan air laut yang telah dicemari dengan air udang busuk dan pakan udang ke dalam sistem biofiltrasi sebagai simulasi cemaran metabolit. Bahan cemaran dipersiapkan dengan cara $100 \mathrm{~g}$ udang dan $100 \mathrm{~g}$ pakan udang dihancurkan dan dibusukkan semalam. Hancuran udang yang sudah membusuk tersebut dilarutkan ke dalam $1 \mathrm{~L}$ air laut.

Pengujian efektivitas sistem biofiltrasi dilakukan dengan memasukkan cairan udang dan pakan udang yang sudah dibusukkan tersebut ke dalam $600 \mathrm{~L}$ air yang akan diuji mutunya. Air yang sudah tercemar tersebut kemudian dialirkan ke dalam sistem biofiltrasi yang telah dirakit. Air yang keluar dari sistem biofiltrasi diamati mutunya tiap 30 menit selama 2 jam berturut turut. Pengamatan mutu air dilakukan terhadap $\mathrm{pH}$, salinitas, kandungan nitrit, amonia, dan protein serta mutu secara organoleptik (bau, warna, dan kekeruhan) pada setiap tahap filtrasi (filter pasir dan koral).

\section{Konstruksi penampungan lobster dengan bak bertingkat}

Penampungan lobster dirancang dengan menggunakan bak bertingkat tiga yang terdiri atas 2 bak pada setiap tingkat dengan menggunakan resirkulasi aliran air secara kontinyu (sistem tertutup). Air bersih setelah difiltrasi dialirkan ke dalam bak penampung lobster, sedangkan air yang keluar dari bak penampung lobster dialirkan ke dalam penampung air buangan kemudian dialirkan ke dalam bak pasir. Dari bak pasir, air dialirkan ke dalam sistem biofiltrasi dan air yang keluar dari sistem biofiltrasi dialirkan kembali ke dalam bak penampungan lobster, demikian seterusnya sehingga air mengalir secara terus- menerus. Bak penampung lobster dilengkapi dengan aerator dan sirkulator untuk meningkatkan jumlah oksigen yang terlarut. Ketinggian air pada bak penampung diatur sedalam $\pm 12 \mathrm{~cm}$ dengan cara melubangi salah satu sisi bak untuk saluran air keluar.

\section{Pengujian penampungan lobster hidup dalam rak bertingkat}

Pada percobaan ini dilakukan uji penampungan lobster untuk mempelajari proses yang terjadi selama penampungan dalam bak bertingkat dengan sistem aliran tertutup. Pengujian dilakukan dengan cara menampung lobster sebanyak 20 ekor yang berukuran size 3 (+300 g) pada masing-masing bak. Selama penampungan lobster diberi pakan berupa potongan udang/ikan 2 kali sehari sebanyak $2 \%$ dari bobot lobster. Penampungan dilakukan selama 1 bulan. Pengamatan dilakukan terhadap kondisi lobster (kematian selama penampungan, perubahan bobot lobster, warna cangkang, serta aktivitas dan respon lobster terhadap rangsangan yang diberikan) dan mutu air selama penampungan.

\section{HASIL DAN BAHASAN}

\section{Pembentukan sistem biofiltrasi}

\section{Pengujian kecepatan aliran air}

Dalam pembentukan sistem biofiltrasi hal yang perlu diperhatikan adalah besarnya aliran air yang keluar, sehingga air mengalir dengan lancar dan tidak terjadi stagnasi. Pada awalnya susunan bahan filtrasi yang digunakan terdiri atas pasir, koral, dan arang dengan susunan yang berselang-seling dalam bak bersekat. Dengan susunan bahan filtrasi seperti ini, ternyata air yang dialirkan dengan menggunakan pompa dengan debit air $20 \mathrm{~L} / m e n i t$ mengalami stagnasi pada filter pasir, sehingga air tumpah keluar dari bak biofiltrasi. Hasil pengukuran kecepatan aliran air pada saluran air keluar dengan susunan bahan filtrasi seperti tersebut di atas hanya sebesar 5,90 L/ menit. Oleh karena itu dicoba untuk menempatkan filter pasir pada bak tersendiri yang lebih besar kapasitasnya, sedang penggunaan arang sebagai bahan biofiltrasi dihilangkan karena menyebabkan air berwarna hitam dan arang mengapung ke mana-mana.

Setelah filter pasir dipisahkan dalam bak tersendiri, besarnya debit air yang keluar dari filter pasir adalah $20 \mathrm{~L} / \mathrm{menit}$. Selanjutnya air yang keluar dari filter pasir dialirkan ke dalam bak biofiltrasi yang berisi filter koral. Hasil pengamatan menunjukkan bahwa kecepatan aliran air pada bak biofiltrasi kolom I dan kolom II masing-masing adalah $12 \mathrm{~L} /$ menit dan $10 \mathrm{~L} /$ menit 
Tabel 1. Hasil pengamatan debit air pada berbagai susunan bahan filtrasi

Table 1. Water debit resulted by different kind of filtration material

\begin{tabular}{lc}
\hline Susunan bahan filtrasi (Filtration material order) & Debit air (Water debit) (L/menit) \\
\hline Pasir, koral, arang dalam bak biofiltrasi & 5.90 \\
(Sand, rock, charcoal in biofiltration tank) & 20 \\
Filter pasir dalam bak tersendiri & 12 \\
(Sand filter in separated tank) & \\
Filter koral pada bak biofiltrasi kolom I & 10 \\
(Rock filter in $1^{\text {st }}$ column biofiltration tank & \\
Filter koral pada bak biofiltarsi kolom II & \\
(Rock filter in $2^{\text {nd }}$ column biofiltration tank) &
\end{tabular}

Besarnya debit air yang diperoleh ini kemudian dimanfaatkan untuk menentukan besarnya debit air di dalam bak penampung lobster. Oleh karena itu aliran air yang masuk ke dalam bak penampungan diatur dengan menggunakan ball valve $0.5^{\text {" sehingga }}$ aliran air pada masing-masing bak penampung mempunyai debit $6-7 \mathrm{~L} /$ menit. Selanjutnya air yang keluar dari bak penampung lobster ditampung pada
Hasil pengamatan efektivitas sistem biofiltrasi terhadap perubahan mutu organoleptik air yang sudah dicemari dengan udang dan pakan ikan busuk sebelum dan sesudah dialirkan ke dalam sistem biofiltrasi dapat dilihat pada Tabel 3. Terlihat bahwa filter pasir yang digunakan dengan ketebalan 15 - 20 $\mathrm{cm}$ sangat efektif untuk menghilangkan bau air yang tercemar udang dan sisa pakan yang dibusukkan. Air yang keluar dari filter pasir tampak jernih dan tidak

Tabel 2. Kandungan jumlah bakteri pada sistem biofiltrasi

Table 2. Total bacterial count of biofiltration system

\begin{tabular}{lcc}
\hline $\begin{array}{c}\text { Umur biofiltrasi } \\
\text { Age of biofiltration }\end{array}$ & $\begin{array}{c}\text { Jumlah bakteri dalam air } \\
\text { Number of bacteria in the } \\
\text { water (cfu/g) }\end{array}$ & $\begin{array}{c}\text { Jumlah bakteri dalam koral } \\
\text { Number of bacteria in the } \\
\text { rock (cfu/g) }\end{array}$ \\
\hline 1 Minggu (1 week) & $44.1 \times 10^{3}$ & $3.72 \times 10^{9}$ \\
2 Minggu (2 weeks) & $16.6 \times 10^{7}$ & $36.24 \times 10^{12}$ \\
4 Minggu (4 weeks) & $18.04 \times 10^{9}$ & $16.48 \times 10^{13}$ \\
\hline
\end{tabular}

bak penampung air buangan dan selanjutnya dialirkan kembali ke dalam filter pasir.

\section{Efektivitas sistem biofiltrasi}

Efektivitas sistem biofiltrasi erat kaitannya dengan jumlah bakteri yang terkandung di dalamnya. Jumlah total bakteri pada air dan koral setelah satu bulan dapat dilihat pada Tabel 2 . Sedangkan efektivitasnya dilakukan dengan cara mengamati mutu air secara organoleptik serta mengamati kemampuan filter untuk mereduksi senyawa metabolit yang bersifat racun.

Dari Tabel 2 terlihat bahwa selama kulturisasi dalam bak biofiltrasi, bakteri dapat tumbuh dengan baik. Setelah satu bulan diinokulasikan dalam sistem biofiltrasi, jumlah bakteri air laut adalah $10^{9} \mathrm{sel} / \mathrm{g}$ sedangkan pada koral adalah $10^{13} \mathrm{sel} / \mathrm{g}$. Jumlah bakteri inilah yang dimanfaatkan kemampuannya untuk mereduksi senyawa-senyawa metabolit lobster seperti nitrit dan amonia selama penampungan. ada partikel-pertikel atau kotoran lainnya, yang menunjukkan bahwa filter tersebut mampu menyaring partikel-partikel yang berukuran kecil

Sedangkan kemampuan sistem biofiltrasi dalam mereduksi senyawa metabolit yang diamati sebelum dan sesudah difiltrasi dapat dilihat pada Tabel 4. Inokulasi udang busuk ke dalam air yang digunakan untuk simulasi ternyata menyebabkan turunnya nilai $\mathrm{pH}$ air laut dari pH air laut normal $(7,84)$ menjadi sedikit asam $(6,84)$.

Dari Tabel 4 terlihat bahwa sistem biofiltrasi yang terbentuk setelah berumur 2 minggu ternyata dapat memperbaiki keasaman air dari pH6,84 menjadi 7,78 yaitu $\mathrm{pH}$ normal air laut setelah dialirkan ke dalam sistem biofiltrasi selama 1 jam dan menjadi 7,82 setelah dialirkan selama 2 jam. Menurut Boothroyd (1994), pH air laut secara normal bersifat sedikit basa yaitu berkisar antara 7,6-8,3. 
Tabel 3. Efektivitas sistem biofiltrasi terhadap mutu organoleptik air Table 3. Effectivity of biofiltration system on the organoleptic quality of water

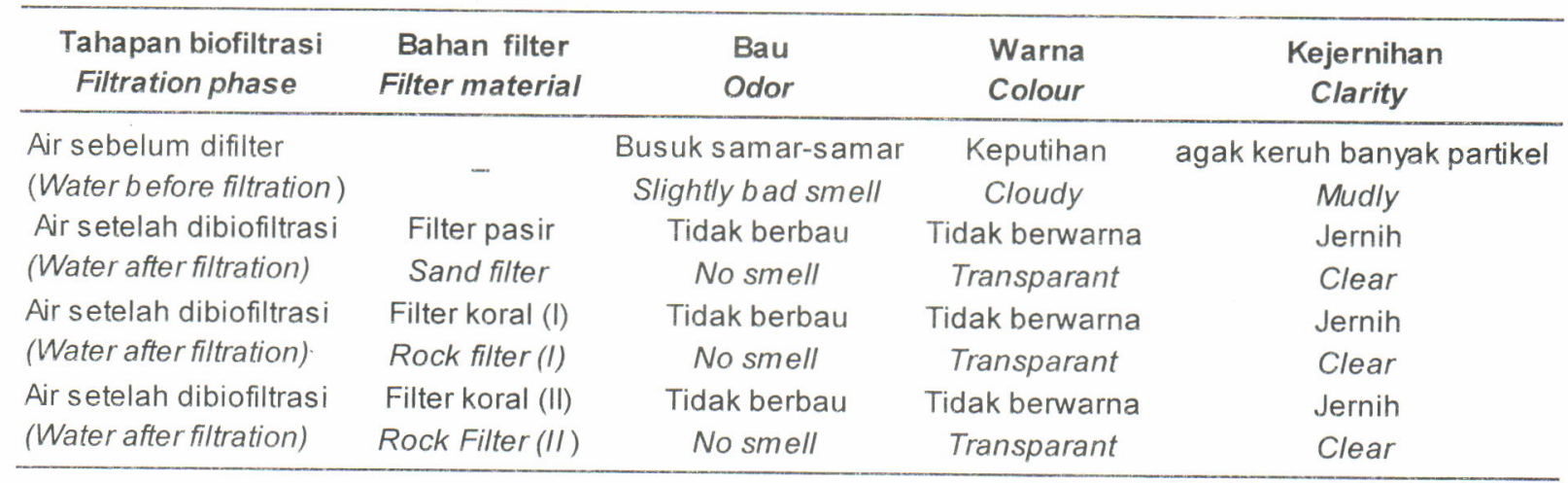

Tabel 4. Efektivitas sistem biofiltrasi pada berbagai waktu pengamatan

Table 4. Effectivity of biofiltration system at different time of filtration

\begin{tabular}{|c|c|c|c|c|c|}
\hline $\begin{array}{l}\text { Lama waktu filtrasi } \\
\text { Period filtration }\end{array}$ & $\begin{array}{l}\text { Jenis filter } \\
\text { Kinds of filter }\end{array}$ & $\begin{array}{c}\mathrm{pH} \\
\mathrm{pH}(\mathrm{ppt})\end{array}$ & $\begin{array}{c}\text { Nitrit } \\
\text { Nitrit }(m g / L)\end{array}$ & $\begin{array}{c}\text { Amonia } \\
\text { Ammonia }(m g / L)\end{array}$ & $\begin{array}{c}\text { Protein } \\
\text { Protein }(M g N \%)\end{array}$ \\
\hline \multirow{2}{*}{\multicolumn{6}{|c|}{$\begin{array}{l}\text { Air sebelum difilter } \\
\text { Water before filtration }\end{array}$}} \\
\hline & & 6.84 & 0.08 & 0.164 & 0.51 \\
\hline \multirow{2}{*}{$\begin{array}{l}0 \text { menit setelah difiltrasi } \\
\text { O menit after filtration }\end{array}$} & $\begin{array}{l}\text { Filter Pasir } \\
\text { Sand filter }\end{array}$ & 6.95 & 0.072 & 0.14 & 0.51 \\
\hline & $\begin{array}{l}\text { Filter koral } \\
\text { Rock filter }\end{array}$ & 7.55 & 0.060 & 0.126 & 0.19 \\
\hline \multirow{2}{*}{$\begin{array}{l}30 \text { menit setelah difiltrasi } \\
30 \text { menit after filtration }\end{array}$} & $\begin{array}{l}\text { Filter pasir } \\
\text { Sand filter }\end{array}$ & 7.60 & 0.055 & 0.158 & 0.39 \\
\hline & $\begin{array}{l}\text { Filter koral } \\
\text { Rock filter }\end{array}$ & 7.58 & 0.057 & 0.127 & 0.51 \\
\hline \multirow{2}{*}{$\begin{array}{l}60 \text { menit setelah difiltrasi } \\
60 \text { menit after filtration }\end{array}$} & $\begin{array}{l}\text { Filter pasir } \\
\text { Sand filter }\end{array}$ & 7.83 & 0.062 & 0.160 & 0.42 \\
\hline & $\begin{array}{l}\text { Filter koral } \\
\text { Rock filter }\end{array}$ & 7.78 & 0.063 & 0.147 & 0.39 \\
\hline \multirow{2}{*}{$\begin{array}{l}90 \text { menit setelah difiltrasi } \\
90 \text { menit setelah difiltrasi }\end{array}$} & $\begin{array}{l}\text { Filter pasir } \\
\text { Sand filter }\end{array}$ & 7.51 & 0.066 & 0.122 & 0.36 \\
\hline & $\begin{array}{l}\text { Filter koral } \\
\text { Rock filter }\end{array}$ & 7.83 & 0.069 & 0.085 & 0.39 \\
\hline \multirow{2}{*}{$\begin{array}{l}2 \text { jam setelah difiltrasi } \\
2 \text { hours after filtration }\end{array}$} & $\begin{array}{l}\text { Filter pasir } \\
\text { Sand filter }\end{array}$ & 7.54 & 0.070 & 0.083 & 0.36 \\
\hline & $\begin{array}{l}\text { Filter koral } \\
\text { Rock filter }\end{array}$ & 7.82 & 0.069 & 0.085 & 0.42 \\
\hline
\end{tabular}

Catatan (Note): Oksigen terlarut 9 (Disolved oxygen) $5.54-7.24 \mathrm{mg} / \mathrm{L}$; suhu (temperature) $26.5^{\circ} \mathrm{C}-26.8^{\circ} \mathrm{C}$

Kemampuan sistem biofiltrasi untuk mereduksi kandungan amonia di dalam air ternyata cukup efektif. Hal ini ditunjukkan dengan menurunnya kandungan amonia dalam air yang dicemari udang busuk. Mulamula kandungan amonia air yang dicemari udang busuk sebesar 0,164 mg/L; setelah air dialirkan selama 1 jam dalam sistem biofiltrasi, turun menjadi $0,147 \mathrm{mg} / \mathrm{L}$. Penurunan kandungan amonia semakin tajam setelah air dialirkan selama 2 jam dalam sistem biofiltrasi, yaitu menjadi $0,085 \mathrm{mg} / \mathrm{L}$. Kandungan nitrit air juga menurun yaitu dari $0,08 \mathrm{mg} / \mathrm{L}$ turun menjadi $0,069 \mathrm{mg} / \mathrm{L}$; sedangkan kandungan protein dalam air turun dari $0,51 \%$ menjadi $0,42 \%$ setelah dialirkan melalui sistem biofiltrasi selama 2 jam. Penurunan ini kemungkinan disebabkan karena terjadinya remediasi oleh bakteri nitrifikasi, yang mengubah amonia menjadi nitrit dan selanjutnya diubah menjadi nitrat, dan dalam keadaan anaerob diubah menjadi nitrogen (Remmerswaal, 1993). 


\section{Konstruksi sistem penampungan}

Penampungan lobster dirancang dengan menggunakan 2 komponen, yaitu komponen biofiltrasi dan komponen rak bertingkat. Komponen biofiltrasi yang telah dibentuk sebelumnya merupakan unit pengolahan air, yang berfungsi untuk memperbaiki mutu air bekas penampungan lobster sehingga diperoleh air bersih. Selanjutnya air yang keluar dari unit biofiltrasi dialirkan ke dalam masing-masing bak yang digunakan untuk menampung lobster. Air dialirkan dengan menggunakan pipa paralon dan digerakkan dengan pompa sirkulator dengan debit air pada masing-masing bak penampung sebesar $6-7$ $\mathrm{L} /$ detik. Air dari bak penampung lobster dialirkan ke dalam bak penampung air buangan dan selanjutnya dialirkan kembali ke dalam bak biofiltrasi.

Volume air yang digunakan untuk menampung lobster secara keseluruhan sebanyak $\pm 1.500 \mathrm{~L}\left(1,5 \mathrm{~m}^{3}\right)$, yaitu untuk mengoperasikan sistem biofiltrasi sebanyak 600 L dan 145 L untuk setiap bak penampung yang ketinggian airnya diatur $12 \mathrm{~cm}$. Dengan debit air sebesar 6-7 L/menit air di dalam bak penampung diharapkan akan mengalami pergantian air tetap mengalir, untuk mendapatkan stabilitas sistem biofiltrasi dan aliran airnya.

\section{Penampungan lobster dengan bak bertingkat}

Efektivitas sistem penampungan yang dirakit, diuji dengan melakukan penampungan lobster selama 1 bulan. Pengamatan dilakukan terhadap kondisi dan aktivitas lobster serta mutu air yang digunakan untuk penampungan yang dilakukan setiap 2 hari sekali.

\section{Kondisi lobster selama penampungan}

Hasil pengamatan menunjukkan bahwa pada minggu pertama dan kedua tingkat kematian lobster cukup tinggi, sedangkan minggu ke-3 dan ke-4 tidak terjadi kematian (Tabel 5). Tingginya tingkat kematian yang terjadi pada minggu pertama dan kedua, diduga karena lobster harus beradaptasi dengan lingkungan yang baru. Perubahan lingkungan dapat menyebabkan lobster mengalami stres Stres menyebabkan sebagian lobster moulting (ganti kulit), sehingga kondisinya sangat lemah dan mengakibatkan sebagian lobster mati.

Tabel 5. Rata-rata sintasan hidup lobster selama penampungan

Table 5. Average of survival rate of lobster during life holding

\begin{tabular}{|c|c|c|c|c|}
\hline \multirow{2}{*}{$\begin{array}{l}\text { Bak tingkat } \\
\text { Level of tank }\end{array}$} & \multicolumn{4}{|c|}{$\begin{array}{c}\text { Rata-rata sintasan hidup lobster selama penampungan (\%) } \\
\text { Average of survival rate of lobster during life holding (\%) }\end{array}$} \\
\hline & $\begin{array}{l}\text { Minggu I } \\
\text { First week }\end{array}$ & $\begin{array}{l}\text { Minggu II } \\
\text { Second week }\end{array}$ & $\begin{array}{l}\text { Minggu III } \\
\text { Third week }\end{array}$ & $\begin{array}{l}\text { Minggu IV } \\
\text { Fouth week }\end{array}$ \\
\hline 1 & 80 & 75 & 75 & 75 \\
\hline 2 & 85 & 75 & 75 & 75 \\
\hline 3 & 95 & 90 & 90 & 90 \\
\hline
\end{tabular}

air secara keseluruhan dengan air bersih paling lambat 30 menit sekali. Sedangkan menurut Muir (1994) dalam penampungan sistem tertutup, diharapkan penggantian air sekurang-kurangnya satu jam sekali. Dengan demikian sistem aliran yang dibentuk sudah memenuhi persyaratan untuk penampungan lobster.

Faktor penting lain yang perlu diperhatikan adalah oksigen terlarut. Untuk meningkatkan jumlah oksigen terlarut dalam air, pada bak penampungan dipasang 3 buah batu aerator. Instalasi aerasi yang dibuat pada bak penampungan lobster dalam penelitian ini, mampu mempertahankan kelarutan oksigen pada masingmasing bak sebesar 5,8-6,6 mg/L. Tingkat kelarutan oksigen tersebut sudah memenuhi persyaratan untuk pemeliharaan lobster dalam jangka waktu lama yaitu berkisar antara 5 - 6 mg/L (Anonymous, 1991). Yang perlu diperhatikan adalah sistem penampungan ini sebelum digunakan, dibiarkan selama 15 hari dengan
Di samping itu kondisi kebugaran lobster juga dapat berpengaruh terhadap tingkat kematian lobster selama penampungan. Menurut Ayres \& Wood (1977), kondisi lobster memegang peranan penting untuk keberhasilan penampungan dalam jangka waktu yang lama, di samping pasok oksigen dan mutu air penampung. Dalam percobaan ini lobster yang kondisinya benar-benar bugar saja yang mampu bertahan selama penampungan.

Kondisi lobster yang kurang bugar, apabila tidak didukung dengan kualitas air yang baik menyebabkan lobster mati. Tingkat kematian yang tinggi yang terjadi pada awal penampungan, diduga juga disebabkan karena terjadinya penambahan air pada bak penampung yang digunakan. Pada awal percobaan, dilakukan penambahan air sekitar $40 \%$ dari volume air yang digunakan untuk penampungan. Penambahan air ini diduga mengganggu stabilitas sistem biofiltrasi yang sudah terbentuk dan berakibat berkurangnya 
jumlah bakteri dalam sistem biofiltrasi, sehingga efektivitas sistem biofiltrasi tidak bekerja dengan baik. Ketidakstabilan sistem biofiltrasi ini ditunjukkan dengan tingginya kandungan nitrit dalam air pada 2 minggu pertama seperti terlihat pada Tabel 9. Memasuki minggu ke-3 dan ke-4, lobster tidak ada yang mati bahkan lobster bertambah bugar. Pada akhir penampungan rata-rata persentase lobster pada bak pertama tinggal $75 \%$ ( 15 ekor), bak kedua $75 \%$ (15 ekor), dan bak ketiga sebesar $90 \%$ (18 ekor).

Pengamatan terhadap aktivitas dan kondisi lobster selama penampungan dapat dilihat pada Tabel 6. Pada awal penampungan perubahan lingkungan menyebabkan lobster stres, sehingga sebagian lobster moulting (ganti kulit) dan sebagian mengalami perubahan warna cangkang dari hijau kebiruan menjadi agak kemerahan. Pada minggu pertama sebagian lobster belum mau makan, sehingga aktivitasnya agak berkurang. Jika pakan yang diberikan tidak segera dimakan, maka air menjadi berbuih dan mempengaruhi kualitas air dalam bak penampung.

Tabel 6. Kondisi lobster selama penampungan

Table 6. Lobster conditions during life holding
Selama penampungan bobot lobster per ekornya relatif tidak berubah, bahkan ada yang mengalami kenaikan. Bobot rata-rata lobster pada bak tingkat 1 mula-mula sebesar 337 g/ekor dan pada akhir penampungan sebesar $334 \mathrm{~g} / \mathrm{ekor}$. Pada bak tingkat 2 mula-mula bobot per ekor lobster sebesar $325 \mathrm{~g} /$ ekor dan pada akhir penampungan naik menjadi 346 g/ekor. Kenaikan bobot yang cukup nyata terjadi pada lobster yang ditampung pada bak tingkat 3 yaitu dari 324 g/ekor menjadi 355 g/ekor. Dengan demikian sistem penampungan yang dirakit selain dapat digunakan untuk pembugaran kemungkinan juga dapat digunakan untuk pembesaran. Berdasarkan pengamatan lebih lanjut ternyata lobster masih bertahan hidup walaupun telah ditampung selama 6 bulan.

Hal yang periu diperhatikan sebelum penampungan adalah, lobster harus dicuci untuk menghilangkan ektoparasit yang menempel pada tubuhnya. Pada saat penelitian ini pencucian tidak dilakukan, sehingga setelah 2 minggu penampungan lobster terinfeksi

\begin{tabular}{|c|c|}
\hline $\begin{array}{l}\text { Lama Penampungan } \\
\text { Molding periode }\end{array}$ & $\begin{array}{l}\text { Kondisi lobster } \\
\text { Lobster conditions }\end{array}$ \\
\hline Minggu I (1 ${ }^{\text {st }}$ Week) & $\begin{array}{l}\text { Sebagian lobster moulting, aktivitas lamban, tidak mau } \\
\text { makan (Some lobster were moulting, slowin activity, } \\
\text { having a bad appetite) }\end{array}$ \\
\hline Minggu II ( $2^{\text {nd }}$ Week) & $\begin{array}{l}\text { Warna cerah, pola warna kontras, gerakan sangat } \\
\text { gesit, nafsu makan tinggi. (The colour of lobsters were } \\
\text { very bright, very active, and having a good appetite) }\end{array}$ \\
\hline Minggu III ( $3^{\text {td }}$ Week) & $\begin{array}{l}\text { Warna cerah, lobster terinfeksi parasit, gerakan, dan } \\
\text { nafsu makan tinggi (The colour of lobsters were very } \\
\text { bright, very active, and having a good appetite, but } \\
\text { attacked by parasite) }\end{array}$ \\
\hline Minggu IV ( $4^{\text {th }}$ Week) & $\begin{array}{l}\text { Lobster bugar, warna cerah, gerakan gesit, nafsu makan } \\
\text { tinggi ( Lobsters were very healtiy, the colour were very } \\
\text { bright, very active, and having a good appetite) }\end{array}$ \\
\hline
\end{tabular}

Memasuki minggu ke-2 penampungan, gerak lobster sangat gesit, jika diberi rangsangan dari luar anthena ditegakkan dan jika disentuh dengan cepat lobster mundur ke belakang. Pada waktu lobster diberi pakan, mereka saling berebut untuk mendapatkannya dan dalam waktu singkat pakan segera habis, sehingga tidak ada sisa pakan yang tertinggal. Warna cangkang menjadi cerah, bagian dorsal berwarna hijau cemerlang dan pada ruas antar karapak berwarna coklat tajam. Warna pada tubuh lobster terlihat kontras sehingga pola warna terlihat jelas. ektoparasit yang menempel pada bagian karapaks dan pangkal kaki. Menurut Frose (1996), untuk menghilangkan ektoparasit pada ikan pencucian dapat dilakukan dengan menggunakan larutan malachite green dengan dosis $0,6 \mathrm{mg}$ per $10 \mathrm{~L}$ air.

\section{Mutu air selama penampungan}

Hasil pengamatan mutu organoleptik air pada bak penampung lobster yang meliputi kejernihan, warna. bau, dan buih menunjukkan bahwa kondisi air selama penampungan cukup jernih, tidak berwarna, dan tidak berbau. Kadang-kadang air berbuih, terutama setelah 
Tabel 7. Rata-rata bobot lobster selama penampungan

Table 7. Average weight of lobster during life holding

\begin{tabular}{ccc}
$\begin{array}{c}\text { Tingkat bak } \\
\text { Level holding tank }\end{array}$ & $\begin{array}{c}\text { Rata-rata bobot pada awal } \\
\text { penampungan } \\
\text { Average weight of start holding }\end{array}$ & $\begin{array}{c}\text { Rata-rata bobot setelah } \\
\text { Average weight after holding }\end{array}$ \\
\hline 1 & $337 \mathrm{~g}$ & $334 \mathrm{~g}$ \\
2 & $325 \mathrm{~g}$ & $346 \mathrm{~g}$ \\
3 & $324 \mathrm{~g}$ & $355 \mathrm{~g}$ \\
\hline
\end{tabular}

lobster diberi pakan dan pakan tersebut tidak segera dihabiskan. Buih pada bak penampung tersebut dapat dihilangkan dengan menyemprotkan air ke dinding bak dengan pompa sirkulator. Tetapi biasanya buih akan hilang dengan sendirinya setelah sirkulasi air berjalan 1 - 2 jam. Selama penampungan bak dibersihkan dari kotoran yang berupa rontokan telur atau patahanpatahan cangkang bekas lobster moulting dengan cara penyifonan. Patahan-patahan cangkang yang mengendap pada bak penampung, apabila tidak segera dibersihkan akan menyebabkan penurunan mutu air, akibat terjadinya proses pembusukan.

Pengamatan pada bak penampung air buangan menunjukkan bahwa pada awal penampungan air agak keruh, berbuih, banyak partikel berupa sisa makanan, telur dan patahan cangkang dan air berbau amis. Air pada bak kotor ini setelah 10 hari penampungan menjadi tidak berbuih dan tidak berbau. Perubahan mutu air ini disebabkan semakin bugar dan meningkatnya nafsu makan lobster, sehingga pakan yang diberikan cepat habis. Hasil pengamatan menunjukkan bahwa air setelah difiltrasi menjadi jernih, tidak ada kotoran, tidak berbuih, dan tidak berbau. Oksigen terlarut pada air setelah dua minggu penampungan berkisar antara 5,55-7,13 $\mathrm{mg} / \mathrm{L}$ dan setelah memasuki minggu ke-3 dan ke-4 menjadi berkisar antara $7,59-8,19 \mathrm{mg} / \mathrm{L}$. Hasil pengukuran $\mathrm{pH}$ air menunjukkan bahwa pada minggu pertama penampungan. air bersifat agak asam dengan $\mathrm{pH}$ berkisar antara $6,47-7,13$ dan pada minggu ke-3 dan ke-4 $\mathrm{pH}$ air pada bak penampung, normal kembali pada $\mathrm{pH}$ air laut normal yaitu berkisar antara 7,58 7,89 .

Hasil analisis kimiawi kandungan amonia air selama penampungan dapat dilihat pada Tabel 8. Pada Tabel 8 terlihat bahwa kandungan amonia yang keluar dari bak biofiltrasi lebih kecil dibandingkan dengan kandungan amonia pada bak penampung lobster dan

Tabel 8. Hasil analisis amonia ( $\mathrm{mg} / \mathrm{L})$ selama penampungan lobster

Table 8. Result of ammonia ( $\mathrm{mg} / \mathrm{L})$ analysis of water during life holding of lobster

\begin{tabular}{|c|c|c|c|c|c|c|}
\hline \multirow{2}{*}{$\begin{array}{c}\text { Waktu (Hari) } \\
\text { Time (days) }\end{array}$} & \multicolumn{3}{|c|}{$\begin{array}{l}\text { Bak penampung lobster } \\
\text { Lobster Holding tank }\end{array}$} & \multirow{2}{*}{$\begin{array}{c}\text { Bak penampung } \\
\text { air buangan } \\
\text { Waste water } \\
\text { holding tank }\end{array}$} & \multicolumn{2}{|c|}{$\begin{array}{l}\text { Air keluar dari filter } \\
\text { Outlet water from filter }\end{array}$} \\
\hline & 1 & 2 & 3 & & $\begin{array}{l}\text { Pasir } \\
\text { Sand }\end{array}$ & $\begin{array}{l}\text { Koral } \\
\text { Rock }\end{array}$ \\
\hline 0 & 0.047 & 0.060 & 0.084 & 0.085 & 0.060 & 0.022 \\
\hline 2 & 0.051 & 0.063 & 0.073 & 0.085 & 0.066 & 0.034 \\
\hline 4 & 0.050 & 0.068 & 0.068 & 0.086 & 0.048 & 0.037 \\
\hline 6 & 0.007 & 0.006 & 0.006 & 0.006 & 0.006 & 0.005 \\
\hline 8 & 0.015 & 0.031 & 0.031 & 0.027 & 0.009 & 0.004 \\
\hline 10 & 0.038 & 0.067 & 0.087 & 0.099 & 0.051 & 0.014 \\
\hline 12 & 0.020 & 0.062 & 0.062 & 0.054 & 0.012 & 0.004 \\
\hline 14 & 0.041 & 0.083 & 0.083 & 0.085 & 0.064 & 0.005 \\
\hline 16 & 0.042 & 0.007 & 0.007 & 0.009 & 0.001 & 0.001 \\
\hline 18 & 0.001 & 0.015 & 0.002 & 0.002 & 0.001 & 0.001 \\
\hline 20 & 0.011 & 0.015 & 0.015 & 0.028 & 0.009 & 0.001 \\
\hline 22 & 0.016 & 0.024 & 0.041 & 0.039 & 0.003 & 0.001 \\
\hline 24 & 0.036 & 0.071 & 0.018 & 0.018 & 0.001 & 0.001 \\
\hline 26 & 0.004 & 0.007 & 0.027 & 0.021 & 0.001 & 0.001 \\
\hline 28 & 0.011 & 0.018 & 0.037 & 0.029 & 0.004 & 0.003 \\
\hline 30 & 0.004 & 0.006 & 0.005 & 0.006 & 0.004 & 0.003 \\
\hline
\end{tabular}


air buangan. Hal ini menunjukkan bahwa sistem biofiltrasi yang dibentuk mampu mereduksi kandungan amonia cukup efektif. Kandungan amonia dalam air yang keluar dari bak biofiltrasi berkisar antara 0,001 - 0,037 mg/L. Sedangkan selama penampungan kandungan amonia dalam bak penampung lobster berkisar antara 0,001 - 0,087 mg/L. Kandungan ini jauh di atas batas maksimum amonia yang diperbolehkan untuk penampungan lobster yaitu sebesar 2,0 mg/L (Boothroyd, 1994). Menurut Mills (1987), dalam sistem filter biologi yang sudah stabil, amonia akan dipecah menjadi nitrit dalam kondisi aerobik oleh bakteri Nitrosomonas dan selanjutnya nitrit dipecah oleh bakteri Nitrobacter menjadi nitrat yang dalam kondisi anaerob dipecah menjadi nitro. gen. rendah, tetapi setelah 2 sampai 12 hari penampungan kandungannya relatif tinggi, dan setelah 14 hari penampungan baru secara perlahan-lahan menurun. $\mathrm{Hal}$ ini menunjukkan bahwa selama 12 hari penampungan, sistem biofiltrasi tidak berjalan secara efektif, sehingga tidak mampu mereduksi kandungan nitrit di dalam air, yang terlihat tidak menurunnya kandungan nitrit yang keluar dari bak biofiltrasi. Menurunnya efektivitas sistem filter biologi ini dapat dikaitkan dengan penambahan air saat penampungan lobster dimulai. Menurut Mills (1987), dalam sistem filter biologi yang sudah stabil, penambahan pasir atau air dari luar ke dalam filter biologi akan menyebabkan terhambatnya kerja sistem biofiltrasi dan memerlukan waktu untuk menjadi baik kembali.

Tabel 9. Hasil analisis nitrit ( $\mathrm{mg} / \mathrm{L}$ ) selama penampungan lobster

Table 9. Result of nitrit ( $\mathrm{mg} / \mathrm{L}$ ) analysis of water during holding of lobster

\begin{tabular}{ccccccc}
\hline Waktu (Hari) & \multicolumn{2}{c}{$\begin{array}{c}\text { Bak penampung lobster } \\
\text { Lobster holding tank }\end{array}$} & $\begin{array}{c}\text { Bak penampung } \\
\text { Time (days) }\end{array}$ & $\begin{array}{c}\text { air buangan } \\
\text { Waste water } \\
\text { holding tank }\end{array}$ & $\begin{array}{c}\text { Air keluar dari filter } \\
\text { Outlet water from filter }\end{array}$ \\
\cline { 6 - 7 } & 1 & 2 & 3 & $\begin{array}{c}\text { Pasir } \\
\text { Sand }\end{array}$ & $\begin{array}{c}\text { Koral } \\
\text { Rock }\end{array}$ \\
\hline 0 & 0.20 & 0.20 & 0.22 & 0.23 & 0.22 & 0.20 \\
2 & 0.22 & 0.20 & 0.22 & 0.23 & 0.22 & 0.20 \\
4 & 0.27 & 2.81 & 2.77 & 2.87 & 2.83 & 2.79 \\
6 & 3.22 & 3.13 & 3.24 & 3.09 & 3.03 & 3.09 \\
8 & 1.14 & 1.25 & 1.28 & 1.35 & 2.01 & 1.16 \\
10 & 0.96 & 0.99 & 0.97 & 0.97 & 1.04 & 0.99 \\
12 & 1.34 & 1.35 & 1.38 & 1.33 & 1.58 & 1.35 \\
14 & 1.14 & 1.17 & 1.23 & 1.33 & 1.42 & 1.05 \\
16 & 0.89 & 0.88 & 0.94 & 0.99 & 1.16 & 0.99 \\
18 & 0.5 & 0.49 & 0.52 & 0.51 & 0.65 & 0.49 \\
20 & 0.07 & 0.07 & 0.08 & 0.08 & 0.13 & 0.07 \\
22 & 0.08 & 0.09 & 0.10 & 0.11 & 0.16 & 0.08 \\
24 & 0.06 & 0.07 & 0.10 & 0.13 & 0.25 & 0.12 \\
26 & 0.09 & 0.08 & 0.08 & 0.11 & 0.12 & 0.09 \\
28 & 0.05 & 0.06 & 0.08 & 0.15 & 0.10 & 0.05 \\
30 & 0.16 & 0.15 & 0.13 & 0.15 & 0.23 & 0.19 \\
\hline
\end{tabular}

Dalam penelitian ini koral sebagai media bakteri sebagian diaerasi dan sebagian tidak, untuk mendapatkan suasana aerob dan anaerob. Pada kondisi ini diharapkan bahwa bakteri yang bersifat aerob dan anaerob dapat berkembang biak. Dengan memanfaatkan kemampuan bakteri tersebut dalam memecah senyawa metabolit yang bersifat racun maka sistem biofiltrasi dapat mempertahankan mutu air selama penampungan.

Hasil pengamatan terhadap kandungan nitrit selama penampungan dapat dilihat pada Tabel 9. Kandungan nitrit pada awal penampungan cukup
Dalam penelitian terlihat bahwa ketidak-stabilan sistem biofiltrasi, menyebabkan tidak terpecahnya nitrit menjadi nitrat oleh bakteri pemecah nitrat Nitrobacter sehingga terjadi akumulasi nitrit di dalam air. Setelah 12 hari penampungan nampak bahwa sistem biofiltrasi biologi yang digunakan sudah stabil yang diperlihatkan dengan menurunnya kandungan nitrit selama penampungan. Walaupun kandungan nitrit selama 12 hari penampungan relatif tinggi, tetapi kandungan ini jauh lebih kecil dibandingkan dengan kadungan nitrit yang bersifat racun terhadap lobster yaitu sebesar $100 \mathrm{mg} / \mathrm{L}$ (Coklin \& Chang, 1983). 
Kandungan $\mathrm{CO}_{2}$ air selama penampungan juga cenderung menurun seperti terlihat pada Tabel 10. Demikian juga kandungan $\mathrm{CO}_{2}$ air yang keluar bak biofiltrasi lebih rendah dari kandungan $\mathrm{CO}_{2}$ air dalam bak penampung lobster atau bak air buangan. Hal ini menunjukkan bahwa biofiltrasi mampu menurunkan kadar $\mathrm{CO}_{2}$. Kadar $\mathrm{CO}_{2}$ selama penampungan relatif metabolik amonia dari $0,164 \mathrm{mg} / \mathrm{L}$ menjadi $0,085 \mathrm{mg} /$ $\mathrm{L}$; nitrit dari $0,08 \mathrm{mg} / \mathrm{L}$ menjadi $0,069 \mathrm{mg} / \mathrm{L}$ dan protein dari $0,51 \%$ menjadi $0,42 \%$ setelah air dialirkan dalam sistem biofiltrasi selama 2 jam. Penambahan air pada sistem biofiltrasi akan mengganggu kestabilan sistem biofiltrasi.

Tabel 10. Hasil analisis $\mathrm{CO}_{2}(\mathrm{mg} / \mathrm{L})$ selama penampungan lobster

Table 10. Result of $\mathrm{CO}_{2}(\mathrm{mg} / \mathrm{L})$ analysis of water during holding of lobster

\begin{tabular}{|c|c|c|c|c|c|c|}
\hline \multirow{2}{*}{$\begin{array}{l}\text { Waktu (hari) } \\
\text { Time (days) }\end{array}$} & \multicolumn{3}{|c|}{$\begin{array}{c}\text { Bak penampung lobster } \\
\text { Lobster holding tank }\end{array}$} & \multirow{2}{*}{$\begin{array}{c}\text { Bak penampung } \\
\text { air buangan } \\
\text { Waste water } \\
\text { holding tank }\end{array}$} & \multicolumn{2}{|c|}{$\begin{array}{l}\text { Air keluar dari filter } \\
\text { Outlet water from filter }\end{array}$} \\
\hline & 1 & 2 & 3 & & $\begin{array}{l}\text { Pasir } \\
\text { Sand }\end{array}$ & $\begin{array}{l}\text { Koral } \\
\text { Rock }\end{array}$ \\
\hline 0 & 2.75 & 2.97 & 3.08 & 3.08 & 2.53 & 1.65 \\
\hline 2 & 4.29 & 4.62 & 4.30 & 3.30 & 3.52 & 3.08 \\
\hline 4 & 1.43 & 3.41 & 2.09 & 4.34 & 4.18 & 2.75 \\
\hline 6 & 1.87 & 2.09 & 2.18 & 2.69 & 2.31 & 1.39 \\
\hline 8 & 1.58 & 1.29 & 1.76 & 2.64 & 1.65 & 1.06 \\
\hline 10 & 3.89 & 3.52 & 3.06 & 3.08 & 3.04 & 2.95 \\
\hline 12 & 1.49 & 1.76 & 1.76 & 2.53 & 1.81 & 0.82 \\
\hline 14 & 1.83 & 1.87 & 1.81 & 2.39 & 2.08 & 1.40 \\
\hline 16 & 1.16 & 1.37 & 1.24 & 2.01 & 1.84 & 1.10 \\
\hline 18 & 1.32 & 1.76 & 1.87 & 1.09 & 1.98 & 0.88 \\
\hline 20 & 1.32 & 1.34 & 1.33 & 1.79 & 1.32 & 1.13 \\
\hline 22 & 1.10 & 1.26 & 1.26 & 1.70 & 1.10 & 0.93 \\
\hline 24 & 1.21 & 1.15 & 1.32 & 1.76 & 1.70 & 0.98 \\
\hline 26 & 0.75 & 0.82 & 1.02 & 1.19 & 1.14 & 0.75 \\
\hline 28 & 0.90 & 1.30 & 1.30 & 1.30 & 1.35 & 0.89 \\
\hline 30 & 0.76 & 1.15 & 1.15 & 1.25 & 1.24 & 0.79 \\
\hline
\end{tabular}

kecil, berkisar antara 0,75-4,34 mg/L; sedangkan kadar $\mathrm{CO}_{2}$ yang mematikan ikan berkisar antara 50 $100 \mathrm{mg} / \mathrm{L}$.

\section{KESIMPULAN}

Sistem biofiltrasi yang dibentuk terdiri atas 2 unit filter yaitu filter pasir yang ditempatkan dalam bak tersendiri dengan debit air $20 \mathrm{~L} /$ menit dan filter koral dalam bak bersekat dengan debit air sebesar $10 \mathrm{~L} /$ menit. Selama penampungan sistem biofiltrasi yang dibentuk ternyata cukup efektif dalam mempertahankan mutu air dan mampu mereduksi senyawa metabolik beracun hingga aman untuk penampungan lobster dalam jangka waktu lebih dari satu bulan.

Sistem biofiltrasi yang dibentuk setelah 2 minggu mempunyai kandungan bakteri sebesar $36.24 \times 10^{12}$ $\mathrm{sel} / \mathrm{g}$ dan mampu memperbaiki keasaman air yang bersifat agak asam $(\mathrm{pH} 6,84)$ menjadi air laut normal $(\mathrm{pH} 7,82)$ dan mampu mereduksi senyawa-senyawa
Penampungan lobster dengan menggunakan bak penampung dalam rak bertingkat yang dilengkapi dengan unit biofiltrasi, dapat menjaga kebugaran lobster selama 30 hari lebih. Kematian lobster yang terjadi pada minggu ke-1 dan ke-2 disebabkan selain tingkat kebugaran lobster yang kurang, juga disebabkan terganggunya sistem biofiltrasi yang dibentuk, karena adanya penambahan air selama penampungan. Selama penampungan biofiltrasi yang dibentuk mampu mereduksi senyawa-senyawa metabolit lobster hingga batas aman untuk penampungan dalam jangka waktu lama dan lobster tidak mengalami penurunan bobot individu per ekornya.

\section{SARAN}

Dalam penampungan lobster sistem tertutup yang dilengkapi dengan sisem biofiltrasi maka yang perlu diperhatikan adalah kebersihan dari bak penampung lobster, jumlah oksigen terlarut (6-7 $\left.\mathrm{mgO}_{2} / \mathrm{L}\right)$, kecepatan aliran air minimal $1 \mathrm{~L} / \mathrm{kg}$ bobot lobster/menit serta suhu air selama penampungan sebaiknya kurang 
dari $27^{\circ} \mathrm{C}$. Jika selama penampungan diperlukan penggantian air, maka penggantian air sebaiknya dilakukan kurang lebih $40 \%$ dari jumlah air yang digunakan.

\section{DAFTAR PUSTAKA}

Anonymous. 1991. Warta Akuakultur No. 2, Vol. 1. Infofish. Kualalumpur Malaysia. p. 41-42.

Ayres. P.A. and P.C. Wood. 1977. The live storage of lobster. Lab Leafl. MAFF Direct Fish Ress. Lowetoft No. 37. $13 \mathrm{pp}$

Basyarie. A. 1990. Transportasi Ikan Hidup. Latihan Penangkapan. Aklimatisasi dalam Transportasi Ikan Hias Laut. Jakarta. $19 \mathrm{pp}$.

Berka, R. 1986. The transport of live fish. A Review. EIFAC Tech.Pap. FAO (48); 52 pp

Boothroyd, F.A. 1994. Handling and maintaining live canadian Atlantic lobster. Infofish International 6. p. 27-32.

Coklin, D.E. and Chang, E.S. 1983. Grow out techniques for the American lobster Humarus americanus. In: CRC Hand Book of Marine Culture Vol. I. James P. and Robert M (Eds). CRC Press Inc. Boca Ratton. Florida. 277-286.

Froze, R. 1996. How to transport live fish in plastic bags. Technical Paper FAO. Roma. p. 35-43.

Mills, D. 1987. Tropical Aquarium Fishes. How to keep marine fish. Chancelor Press. London. p. 26-31.

Muir, J.F. 1994. Water reused system in aquaculture. Infofish International No. 6:40 - 49 .

Praseno, O. 1990. Cara Pengiriman/Transportasi Ikan dalam Keadaan Hidup. Balai Penelitian Perikanan Air Tawar. Bogor. $15 \mathrm{pp}$

Remmerswaal, R.A.M. 1993. Recirculating Aquaculture Systems. Infofish Technical Handbooks 8. 27 pp.

Suastika, K.J.A. Tashlim, A. Nur. 1996. Penerapan teknik produksi dan preservasi bakteri remediasi. Techner 27. Tahun IV. p. 12-14.

Wibowo, S. 1993. Sumberdaya Lobster di Jawa-Bali dan Transportasi Lobster Hidup. Makalah Disampaikan pada Seminar Peluang dan Tantangan Ekspor Produk Perikanan di Yogyakarta. 25 Oktober 1993. $19 \mathrm{pp}$. 